\title{
PERAN CITRA MEREK MEMEDIASI PENGARUH KEWAJARAN HARGA TERHADAP KEPUTUSAN PEMBELIAN PRODUK ONLINESHOP ZALORA DI DENPASAR
}

\author{
Ni Putu Lely Wahyuni ${ }^{1}$ \\ Gede Bayu Rahanatha ${ }^{2}$ \\ Fakultas Ekonomi dan Bisnis Universitas Udayana (Unud), Bali, Indonesia \\ e-mail: lelywahyuni2108@gmail.com
}

\begin{abstract}
ABSTRAK
Berbelanja secara olinemenjadi salah satu tren yang berkembang saat ini. Perkembangan teknologi mendukung semakin pesatnya perkembangan online shop dan mempermudah konsumen dalam berbelanja.Konsumen saat ini lebih selektif dalam melakukan keputusan pembelian, konsumen cenderung memilih produk dengan citra merekyang baik dan harga yang sesuai.Penelitian ini bertujuan untuk dapat mengetahui bagaimana pengaruh kewajaran hargapada keputusan pembelian dengan citra mereksebagai variabel pemediasi. Melihat potensi pasar online saat ini khususnya dalam hal fashion, maka penelitian ini mengangkat objek keputusan pembelian produk fashion online shop Zalora dengan responden konsumen yang pernah berbelanja secara online di Kota Denpasar. Metode survey yang dilakukan menggunakan teknik wawancara dengan kuisioner dan diukur dengan skala likert. Data hasil jawaban oleh responden kemudian dianalisis dengan denganPath Analysis danUji Sobel untuk menguji hipotesis yang telah dirumuskan. Hasil penelitian ini menunjukan variabel citra merekmampu memediasi pengaruh kewajaran hargaterhadap keputusan pembelian konsumen.
\end{abstract}

Kata kunci: kewajaran harga, citra merek, keputusan pembelian

\begin{abstract}
Online shopping is one of trend that is growing rapidly nowadays. Now the technological advancement supported rapid growth of the online shopping and make it easier for consumer to shopping. Consumer is more selective to make purchase decision, consumer tend to chose product that have good brand image and compatible price. This research aims to find out the influence between price and purchase decision with brand image as a mediation variable. Realizing the potential of market online especially the fashion product, then this research raising the topic with price fairness, brand image and purchase decision as the objects. Respondents are them who have been online purchasing. The survey conducted by spreading questionnaire than measured by likert's scale. Data analyzed by path analysis and sobel test. The result of this research showed than variable brand image capable of being mediated the influence between price fairness and consumer purchase decision.
\end{abstract}

Keywords :price fairness, brand image, purchase decision 


\section{PENDAHULUAN}

Perkembangan media Internet saat ini telah mengalami kemajuan pesat, terutama dalam bidang bisnis online.Semakin banyak website berbelanja online yang ada saat ini menjadi contoh nyata perkembangan teknologi yang kian meningkat, hal ini membentuk tren baru dalam masyarakat modern. Widiyanto \& Prasilowati, (2015) mengungkapkan bahwa pertumbuhan teknologi yang pesat menciptakan peluang bisnis baru, internet telah menjadikan bisnis saat ini borderless dan timeless (tanpa batas wilayah dan tanpa batas waktu). Internet telah mengubah cara berbelanja secara tradisional menjadi via online shopping, konsumen tidak lagi harus mengunjungi outlet dan dapat menjadi pelanggan virtual setiap saat dalam pembelian produk maupun jasa (Pahwa et al., 2017). Dilihat dari sisi laininternet sendiri telah menjadi peluang bisnis baru yang cukup menjanjikan.

Praktik nyata dalam bisnis online saat ini telah menggunakan sistem $E$ commerce. Electronic Commerce (e-commerce) merupakan proses pembelian, penjualan, atau pertukaran produk, jasa maupun informasi melalui jaringan komputer, dengan e-commerce prodesen dapat merubah daftar harga ataupun melakukan kustomisasi terhadap produk maupun jasa yang ditawarkan dan menginformasikan langsung dalam website (Irmawati, 2011). E-commerce menawarkan lebih banyak kesempatan dalam pemasaran online bagi perusahaan diseluruh dunia dan mendukung pertumbuhan yang tinggi dalam berbelanja secara online. Perusahaan-perusahaan yang berbisnis secara online tidak perlu memiliki ataupun menyewa sebuah gerai dan dapat meminimalisir biaya bangunan, disisi lain bisnis online memberikan banyak manfaat bagi konsumen mulai dari komunikasi yang lebih interaktif, kemudian kemudahan dalam distribusi dan pengiriman yang efisien dan cepat (Mobarakabadi et al., 2013).

Di Indonesia sendiri perkembangan teknologi saat ini telah mendukung pertumbuhan E-commerce, akses internet yang mudah melalui wifi ataupun perangkat gadget memudahkan masyarakat mengakses informasi menganai produk maupun jasa yang diinginkan, selain itu promosi yang dilakukan oleh perusahaan E-commerce mempermudah akses masyarakat (Sidharta \& Boy Suzanto, 2015). Salah satu perusahaan E-commerce yang bergerak dibidang fashion adalah Zalora. Perusahaan ini merupakan salah satu fashion online shopping terbesar di Asia Tenggara, berdiri sejak tahun 2012 dan telah ada di Singapura, Indonesia, Malaysia, Thailand, Filipina, Hongkong, Vietnam, dan Brunei. Zalora sendiri menawarkan berbagai produk fashion dari berbagai merek ternama. Zalora menawarkan 30 hari pengembalian gratis, pengiriman gratis, pengiriman tercepat 1-3 hari kerja dan menggunakan metode pembayaran cash on delivery atau yang sering disebut dengan COD.

Zalora sebagai salah satu perusahaan E-commerce yang sukses menawarkan produk dengan merek merek ternama menjadi salah satu perusahaan E-commerce yang paling berpengaruh saat ini, dengan menawarkan merek-merek ternama menjadi salah satu keunggulan yang dimiliki Zalora. Menurut Zhang (2015) persepsi konsumen mengenai sebuah merek berpengaruh terhadap perilaku konsumen. Konsumen cenderung akan memilih melakukan pembelian produk dengan merek terkenal dan memilikibrand image yang baik, karena konsumen 
merasa efek resiko yang dirasakan cenderung sedikit (Dodds \& Monroe, 1985) dan (Wang \& Tsai, 2014). Brand image yang baik menjadi salah satu pertimbangan bagi konsumen dalam memilih suatu produk.E-commerce menawarkan banyak kesempatan dalam pemasaran online bagi perusahaan diseluruh dunia, dengan pertumbuhan yang tinggi dalam hal berbelanja online telah banyak pengecer yang menjual produk dan jasanya melalui saluran online untuk memperluas pasar (Akbar \& James, 2012).

Berbagai upaya dilakukan Zalora untuk membangun citra merek yang kuat, diantaranya Zalora menjadi salah satu sponsor dalam penyelenggaraan Asia's Next Top Model Season 3, selanjutnya Zalora mengadakan event penghargaan yang bekerjasama dengan Samsung dan bank BNI yaitu Zalora Style Award. Upaya-upaya tersebut dilakukan Zalora untuk menciptakan brand image yang kuat dalam masyarakat.

Penelitian yang dilakukan Fianto et al., (2014) menunjukan hubungan yang signifikan antara citra merek dengan perilaku pembelian. Citra merek menjadi pertimbangan penting bagi konsumen sebelum melakukan pembelian, citra merek yang baik akan menjadi nilai tambah bagi produk itu sendiri. Membangun reputasi merek yang kuat didukung oleh citra merek yang positif, tanpa dukungan dariadanya citra merek (brand image) yang baik dan positif pada perusahaan, tidak akan mampu mendapatkan sebagian besar pangsa pasar (Durrani \& Lecturer, 2015). Menurut Müller \& Chandon (2003) citra merek (brand image) memiliki sepuluh dimensi yaitu, atribut produk, fitur intangible, manfaat konsumen, harga yang relatif, tempat, momen dan bentuk pemanfaatan, pembeli dan konsumen, karakter yang melekat pada merek, kepribadian merek, katagori produk dan pesaing.

Konsumen akancenderung menjadikan suatu citra merek (band image) sebagai dasar atau acuan sebelum melakukan proses pembelian pada suatu produk ataupun jasa (Fristiana, 2012). Perusahaan dituntut agar mampu menciptakan brand image semenarik mungkin dan dapat menggambarkan bagaimana manfaat produk yang telah sesuai dengan kebutuhan konsumennya, sehingga konsumen akan membangun citra yang positif terhadap merek (brand) tersebut. Semakin menarik sebuah merek dimata konsumen semakin tinggi peluang merek tersebut akan dipilih oleh konsumen. Citra merek menjadi hal penting dalam lingkungan bisnis, sama seperti halnya dalam dunia bisnis online. Perusahaan bersaing dalam memberikan ide yang baik mengenai produk dan layanan yang ditawarkan untuk membangun citra positif dibenak konsumen (Sallam, 2014). Berbisnis secara online membutuhkan lebih banyak kepercayaan dari konsumen, membangun citra merek yang positif akan meningkatkan kepercayaan konsumen terhadap perusahaan tersebut.

Konsumen yang masih belum memiliki informasi ataupun pengalaman terhadap suatu produk, akancenderung lebih mempercayai merek yang telah familiar kemudian disukai banyak orang ataupun merek yang sudah terkenal dikalangan masyarakat (Tjahjono et al., 2013). Alasan-alasan inilah yang menjadi dorongan bagi perusahaan-perusahaan untuk mantap dalam memperkuat posisi citra merek produknya agar mampu menciptakan brand image yang positif danakan menancap dalam benak konsumen. Keadaan pasar dengan 
keanekaragaman produk dengan brand yang ada membuat konsumen dengan leluasa menentukan pilihannya, namun dilain pihak konsumen akan menjadi bingung dengan banyaknya brand yang ditawarkan, konsumen akan mempertimbangkan keputusan pembeliannya dengan melihat citra merek (brand image) yang menurut mereka baik dan positif (Wahyuni \& Suparna, 2014).

Selain citra merek konsumen saat ini akan mempertimbangkan harga untuk setiap produk yang akan mereka beli. Harga menjadi salah satu pertimbangan setiap konsumen, sebagaian besar konsumen bereaksi berbeda terhadap harga, persepsi harga oleh konsumen merupakan interpretasi harga dan penilaian produk oleh konsumen (Geçti, 2014). Harga yang baik akan berpengaruh terhadap keputusan pembelian oleh konsumen (Kenesei \& Todd, 2003). Menurut Chen et al., (2016) persepsi konsumen terhadap nilai merupakan trade-off antara kualitas yang dirasakan dengan manfaat dalam produk terhadap pengorbanan yang dirasakan dengan membayar harga produk tersebut.

Lingkungan pemasaran saat ini, harga dan kualitas produk merupakan isu sentral dalam pengambilan keputusan pembelian dan juga strategi pemasaran perusahaan (Owusu, 2013). Konsumen akan membandingkan besar harga yang harus mereka bayar dengan apa yang mereka dapatkan. Konsumen menjadi lebih selektif terhadap harga suatu produk dan jasa. Konsumen memiliki tingkat kepekaan tersendiri terhadap harga, baik kenaikan harga maupun penurunan harga (Gázquez-Abad \& Martínez-López, 2014). Dapat disimpulkan harga memiliki peranan penting dalam pengambilan keputusan dalam perusahaan, baik perusahaan secara offline maupun online, serta keputusan pembelian yang dilakukan konsumen.

Díaz-Bonilla (2016) menyatakan pentingnya harga bagi konsumen dinyatakan dalam tiga tingkatan berikut, intensitas mencari informasi mengenai harga dan dimensi harga, akurasi harga, bunga harga atu dimensi akurasi. Konsumen akan memutuskan pembeliannya sesuai demham kemampuan yang dimiliki. Harga yang ditetapkan pada produk akan berdampak pada sejauh mana konsumen melihat produk perusahaan tersebut dan menentukan keputusan selanjutnya (Faith \& Edwin, 2014). Konsumen menjadi sangan sensitif terhadap harga yang ditetapkan oleh perusahan, pertimbangan dari berbagai aspek baik harga akan menjadi evaluasi khusus yang dilakukan konsumen.

Perbandingan harga produk maupun jasa online dan offline memiliki pengaruh yang signifikan terhadap pengambilan keputusan pembelian yang akan dilakukan. Harga pada dasarnya adalah sejumlah besaran uang yang bersedia konsumen bayar untuk dipertukarkan dengan produk dan jasa yang dianggap berharga. Besarnya nilai uang bervariasi bagi setiap konsumen, beberapa konsumen berfikir harga tinggi menjamin kualitas suatu produk namun ada pula konsumen yang berfikir harga tersebut terlalu tinggi untuk sejumlah nilai mata uang (Lay-Yee et al., 2013). Persepsi mengenai harga pada setiap konsumen memiliki kecenderungan yang berbeda tergantung bagaimana konsumen dapat menilai bagaimana produk terseut memberi nilai bagi konsumen yang akan membeli.

Penelitian oleh Baubonien \& Gulevičiūt (2015) menunujukan harga berpengaruh secara signifikan dalam berbelanja online. Sebelum melakukan 
keputusan pembelian konsumen akan mempertimbangkan beberapa faktor seperti apakah harga tersebut sesuai dengan produk ataukan harga tersebut mencermintak kualitas dari sebuah brand. Penelitian kali ini mengangkat bagaimana sebuah brand dan harga dapat mempengaruhi keputusan pembelian konsumen khususnya pembelian produk fashion online.

Berdasarkan latar belakang, maka rumusan masalah penelitian adalah sebagai berikut: 1) Apakah Kewajaran hargaberpengaruh terhadap keputusan pembelian produk-produk fashion online shop ZALORA? 2) Apakah Citra merek berpengaruh terhadap keputusan pembelian produk-produk fashion online shop ZALORA? 3) Apakah Kewajaran harga berpengaruh terhadap citra merek produk-produk fashion online shop ZALORA? 4) Apakah Citra merek memediasi pengaruh kewajaran harga terhadap keputusan pembelian produk-produk fashion online shop ZALORA?

Berdasarkan rumusan masalah, maka tujuan dari penelitian ini adalah: 1) Menganalisis pengaruh Kewajaran harga terhadap keputusan pembelian produkproduk fashion online shop ZALORA. 2) Menganalisis pengaruh Citra merek terhadap keputusan pembelian produk-produk fashion online shop ZALORA. 3) Menganalisis pengaruh Kewajaran harga terhadap citra merek produk-produk fashion online shop ZALORA. 4) Menganalisis pengaruh Citra merek dalam memediasi Kewajaran harga terhadap keputusan pembelian produk-produk fashion online shop ZALORA.

Berdasarkan tujuan penelitian yang telah diuraikan, adapun kegunaan dari penelitian ini adalah: 1) Kegunaan Teoritis dari penelitian ini diharapkan dapat digunakan oleh mahasiswa untukdapat mengaplikasikan teori yang didapat dari proses perkuliahan serta memperoleh tambahan pengetahuan dan informasi dari penelitian yang telah dilakukan. 2) Kegunaan Praktis dari hasil penelitian ini bagi peneliti diharapkan dapat digunakan untuk menambah pengalaman dan melatih untuk berfikir kritis dalam menghadapi suatu permasalahan dan sebagai sarana untuk menerapkan ilmu yang diperoleh selama kuliah dalam menyelesaikan permasalahan dalam kehidupan nyata, dan bagi perusahaan yang diteliti diharapkan dapat dijadikan sebagai bahan tambahan informasi perusahaan.

Keputusan pembelian merupakan proses pengambilan keputusan akhir konsumen bahwa konsumen benar-benar akan membeli produk (Kotler \& Keller, 2009). Keputusan sendiri merupakan seleksi terhadap beberapa pilihan alternatif yang ada (Schiffman \& Kanuk, 2010). Konsumen memiliki kesempatan yang sama dalam menentukan pilihan alternatif yang akan dipilih.

Harga merupakan komponen penting atas suatu produk, karena akan mempengaruhi keuntungan produsen. Harga menjadi penentu keberhasilan sebuah perusahaan yang diperoleh dari penjualan produk (Habibah \& Sumiati, 2016). Dalam penelitiannya Habibah \& Sumiati (2016) mengemukakan memiliki pengaruh dominan terhadap keputusan pembelian. Mangkunegara, (2015) menyebutkan bahwa harga berpengaruh signifikan negatif terhadap keputusan pembelian. Harga berpengaruh terhadap keputusan pembelian dikemukakan oleh Mangkunegara (2015) hal serupa juga dikemukakan oleh (Wanda, 2015). Berdasarkan teori dan penelitian sebelumnya maka dapat dirumuskan hipotesis sebagai berikut : 
$\mathrm{H}_{1}$ : Kewajaran harga berpengaruh signifikan terhadap keputusan pembeliaan produk-produk fashion online shop ZALORA.

Harga merupakan sejumlah nilai yang ditukarkan oleh konsumen dengan jumlah manfaat yang dapat dimiliki atas penggunaan suatu barang atau jasa. Harga seringkali digunakan sebagai indicator nilai apabila harga dihubungkan dengan manfaat yang dirasakan. Nugroho, (2014) dalam penelitiannya menyebutkan harga berpengeruh langsung terhadap brand image. Penelitian yang dilakukan Nurul, (2017) menunjukan harga berpengaruh terhadap brand image. Berdasarkan teori dan penelitian sebelumnya maka dapat dirumuskan hipotesis sebagai berikut :

$\mathrm{H}_{2}$ :Kewajaran harga berpengaruh positif dan signifikan terhadap brand image produk-produk fashion online shop ZALORA.

Alasan merek sangat dibutuhkan oleh suatu produk karena merek memiliki nilai yang kuat, manfaat merek seseorang disesuaikan dengan karakteristiknya kemudian barulah diambil keputusan pembelian. Proses tertarik terhadap suatu produk ataupun jasa akan dialami oleh konsumen sebelum melakukan keputusan pembelian (Ambarwati, 2015). Durrani \& Lecturer (2015) dalam penelitiannya menyebutkan bahwa brand image berpengaruh positif terhadap perilaku pembelian konsumen. Rohmah, (2015) menyebutkan brand image berpengaruh positi signifikan terhadap keputusan pembelian, hal serupa juga dikemukakan oleh (Samad \& Wibowo, 2016). Berdasarkan teori dan penelitian sebelumnya maka dapat dirumuskan hipotesis sebagai berikut :

$\mathrm{H}_{3}$ : Citra merekberpengaruh positif dan signifikan terhadap keputusan pembeliaan produk-produk fashion online shop ZALORA.

Brand image merupakan identitas dalam diferensiasi produk dengan perusahaan lain (Rohmah, 2015). Sedangkan harga merupakan cerminan tingkat manfaat yang dirasakan konsumen. Brand yang memiliki citra positif dimasyarakat akan memiliki harga yang sesuai. Penelitian yang dilakukan Lingga, (2016) menyatakan brand image secara signifikan berpengaruh terhadap kepetusan pembelian. Purnamasari (2015) menyatakan harga berpengaruh terhadap keputusan melalui brand image. Berdasarkan teori dan penelitian sebelumnya maka dapat dirumuskan hipotesis sebagai berikut :

$\mathrm{H}_{4}$ : Citra merek memediasi pengaruh kewajaran harga terhadap keputusan pembeliaan produk-produk fashion online shop ZALORA.

Konsumen akancenderung menjadikan suatu citra merek (band image) sebagai dasar atau acuan sebelum melakukan proses pembelian pada suatu produk ataupun jasa (Fristiana, 2012). Perusahaan dituntut agar mampu menciptakan brand image semenarik mungkin dan dapat menggambarkan bagaimana manfaat produk yang telah sesuai dengan kebutuhan konsumennya, sehingga konsumen akan membangun citra yang positif terhadap merek (brand) tersebut. Semakin menarik sebuah merek dimata konsumen semakin tinggi peluang merek tersebut akan dipilih oleh konsumen. Citra merek menjadi hal penting dalam lingkungan bisnis, sama seperti halnya dalam dunia bisnis online. Perusahaan bersaing dalam memberikan ide yang baik mengenai produk dan layanan yang ditawarkan untuk membangun citra positif dibenak konsumen (Sallam, 2014). 


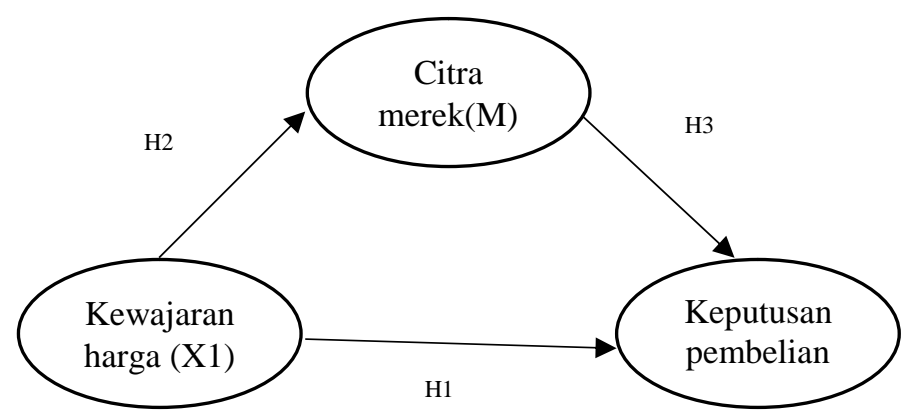

Gambar 1. Model Konseptual Penelitian

Berbisnis secara online membutuhkan lebih banyak kepercayaan dari konsumen, membangun citra merek yang positif akan meningkatkan kepercayaan konsumen terhadap perusahaan tersebut.

Konsumen yang masih belum memiliki informasi ataupun pengalaman terhadap suatu produk, akancenderung lebih mempercayai merek yang telah familiar kemudian disukai banyak orang ataupun merek yang sudah terkenal dikalangan masyarakat (Tjahjono et al., 2013). Alasan-alasan inilah yang menjadi dorongan bagi perusahaan-perusahaan untuk mantap dalam memperkuat posisi citra merek produknya agar mampu menciptakan brand image yang positif danakan menancap dalam benak konsumen. Keadaan pasar dengan keanekaragaman produk dengan brand yang ada membuat konsumen dengan leluasa menentukan pilihannya, namun dilain pihak konsumen akan menjadi bingung dengan banyaknya brand yang ditawarkan, konsumen akan mempertimbangkan keputusan pembeliannya dengan melihat citra merek (brand image) yang menurut mereka baik dan positif (Wahyuni \& Suparna, 2014).

Selain citra merek konsumen saat ini akan mempertimbangkan harga untuk setiap produk yang akan mereka beli. Harga menjadi salah satu pertimbangan setiap konsumen, sebagaian besar konsumen bereaksi berbeda terhadap harga, persepsi harga oleh konsumen merupakan interpretasi harga dan penilaian produk oleh konsumen (Geçti, 2014). Harga yang baik akan berpengaruh terhadap keputusan pembelian oleh konsumen (Kenesei \& Todd, 2003). Menurut Chen et al., (2016) persepsi konsumen terhadap nilai merupakan trade-off antara kualitas yang dirasakan dengan manfaat dalam produk terhadap pengorbanan yang dirasakan dengan membayar harga produk tersebut.

Lingkungan pemasaran saat ini, harga dan kualitas produk merupakan isu sentral dalam pengambilan keputusan pembelian dan juga strategi pemasaran perusahaan (Owusu, 2013). Konsumen akan membandingkan besar harga yang harus mereka bayar dengan apa yang mereka dapatkan. Konsumen menjadi lebih selektif terhadap harga suatu produk dan jasa. Konsumen memiliki tingkat kepekaan tersendiri terhadap harga, baik kenaikan harga maupun penurunan harga (Gázquez-Abad \& Martínez-López, 2014). Dapat disimpulkan harga memiliki peranan penting dalam pengambilan keputusan dalam perusahaan, baik perusahaan secara offline maupun online, serta keputusan pembelian yang dilakukan konsumen. 
Díaz-Bonilla (2016) menyatakan pentingnya harga bagi konsumen dinyatakan dalam tiga tingkatan berikut, intensitas mencari informasi mengenai harga dan dimensi harga, akurasi harga, bunga harga atu dimensi akurasi. Konsumen akan memutuskan pembeliannya sesuai demham kemampuan yang dimiliki. Harga yang ditetapkan pada produk akan berdampak pada sejauh mana konsumen melihat produk perusahaan tersebut dan menentukan keputusan selanjutnya (Faith \& Edwin, 2014). Konsumen menjadi sangan sensitif terhadap harga yang ditetapkan oleh perusahan, pertimbangan dari berbagai aspek baik harga akan menjadi evaluasi khusus yang dilakukan konsumen.

Perbandingan harga produk maupun jasa online dan offline memiliki pengaruh yang signifikan terhadap pengambilan keputusan pembelian yang akan dilakukan. Harga pada dasarnya adalah sejumlah besaran uang yang bersedia konsumen bayar untuk dipertukarkan dengan produk dan jasa yang dianggap berharga. Besarnya nilai uang bervariasi bagi setiap konsumen, beberapa konsumen berfikir harga tinggi menjamin kualitas suatu produk namun ada pula konsumen yang berfikir harga tersebut terlalu tinggi untuk sejumlah nilai mata uang (Lay-Yee et al., 2013). Persepsi mengenai harga pada setiap konsumen memiliki kecenderungan yang berbeda tergantung bagaimana konsumen dapat menilai bagaimana produk terseut memberi nilai bagi konsumen yang akan membeli.

Harga adalah komponen penting dalam suatu produk, karena akan mempengaruhi keuntungan produsen. Harga menjadi penentu keberhasilan sebuah perusahaan yang diperoleh dari penjualan produk (Habibah \& Sumiati, 2016). Terdapat empat indikator dari price yang diadopsi dari instrument yang dikembangkan oleh Achidah et al., (2016) meliputi: Keterjangkauan harga produk, Kesesuaian harga dengan kualitas produk, Daya saing harga tersebut dan Kesesuaian harga dengan manfaat yang dirasakan.

Alasan merek sangat dibutuhkan oleh suatu produk karena merek memiliki nilai yang kuat, manfaat merek seseorang disesuaikan dengan karakteristiknya kemudian barulah diambil keputusan pembelian. Proses tertarik terhadap suatu produk ataupun jasa akan dialami oleh konsumen sebelum melakukan keputusan pembelian (Ambarwati, 2015). Indikator citra merek pada penelitian ini mengacu pada penelitian Fianto et al., (2014) yaitu: Keberadaan, Reputasi, Familiar dan Terpercaya.

Keputusan pembelian itu sendiri merupakan proses pengambilan keputusan akhir konsumen bahwa konsumen benar-benar akan melakukan pembelian terhadap suatu produk (Kotler \& Keller, 2009). Indikator keputusan pembelian pada penelitian ini mengacu pada penelitian Achidah et al., (2016) yaitu: Prioritas pembelian pada produk tersebut, rekomendasi dari orang-orang terdekat dan keinginan untuk membeli ulang.

Penelitian oleh Baubonien \& Gulevičiūt, (2015) menunujukan harga berpengaruh secara signifikan dalam berbelanja online. Sebelum melakukan keputusan pembelian konsumen akan mempertimbangkan beberapa faktor seperti apakah harga tersebut sesuai dengan produk ataukan harga tersebut mencermintak kualitas dari sebuah brand. Penelitian kali ini mengangkat bagaimana sebuah 
brand dan harga dapat mempengaruhi keputusan pembelian konsumen khususnya pembelian produk fashion online.

Bagi perusahaan, persaingan antar online shop saat ini sangat ketat, kedepannya diharapkan ZALORA mampu mampu menetapkan harga yang tepat dan meningkatkan brand image dimata konsumen, brand image yang positif akan menjadi daya Tarik tersendiri bagi online shop ZALORA. Komponen yang perlu ditingkatkan bukan hanya kewajaran harga dan brand image saja namun dapat mempertimbangkan komponen lainnya untuk menunjang keputusan pembelian terhadap produk fashion online shop ZALORA. Memberikan potongan harga khusus, dan memberikan penawaran khusus seperti memposting pada social media membatu Zalora dalam meningkatkan promosi dan menarik minat konsumen untuk membeli ataupun konsumen yang suah pernah membeli untuk melakukan pembelian ulang.

\section{METODE PENELITIAN}

Jenis penelitian adalah bersifat asosiatif. Penelitian ini bertujuan untuk mengetahui pengaruh dan hubungan antar dua variabel atau lebih (Sugiyono, 2014). Pendekatan dalam penelitian ini dengan menggunakan pendekatan survei berupa kuesioner sebagai alat pengumpulan data. Penelitian ini dilakukan di Kota Denpasar. Lokasi ini dipilih dikarenan Kota Denpasar merupakan daerah padat penduduk dengan pertumbuhan dalam sektor ekonomi masyarakatnya yang sangat cepat yang dalam hal ini selera masyarakat sangat terpengaruh terhadap lingkungannya. Subjek dalam penelitian ini merupakan konsumen yang sudah pernah membeli produk fashion secara online. Objek penelitian ini adalah citra merek, kewajaran harga, dan keputusan pembelian produk fashion online.

Berdasarkan jenisnya variabel pada penelitian ini menggunakan variabel terikat, variabel mediasi dan variabel bebas.Variabel terikat dalam penelitian ini adalah keputusan pembelian (Y). Sedangkan variabel bebas pada penelitian ini yaitu variabel Kewajaran harga (X1) dan Citra merek (M) sebagai variabel mediasi.

Harga adalah komponen penting dalam suatu produk, karena akan mempengaruhi keuntungan produsen. Harga menjadi penentu keberhasilan sebuah perusahaan yang diperoleh dari penjualan produk (Habibah \& Sumiati, 2016). Terdapat empat indikator dari price yang diadopsi dari instrument yang dikembangkan oleh Achidah et al., (2016) meliputi: Keterjangkauan harga produk, Kesesuaian harga dengan kualitas produk, Daya saing harga tersebut dan Kesesuaian harga dengan manfaat yang dirasakan.

Alasan merek sangat dibutuhkan oleh suatu produk karena merek memiliki nilai yang kuat, manfaat merek seseorang disesuaikan dengan karakteristiknya kemudian barulah diambil keputusan pembelian. Proses tertarik terhadap suatu produk ataupun jasa akan dialami oleh konsumen sebelum melakukan keputusan pembelian (Ambarwati, 2015). Indikator citra merek pada penelitian ini mengacu pada penelitian Fianto et al., (2014) yaitu: Keberadaan, Reputasi, Familiar dan Terpercaya. 
Keputusan pembelian itu sendiri merupakan proses pengambilan keputusan akhir konsumen bahwa konsumen benar-benar akan melakukan pembelian terhadap suatu produk (Kotler \& Keller, 2009). Indikator keputusan pembelian pada penelitian ini mengacu pada penelitian Achidah et al., (2016) yaitu: Prioritas pembelian pada produk tersebut, rekomendasi dari orang-orang terdekat dan keinginan untuk membeli ulang.

Berdasarkan sumbernya, data penelitian dapat dikelompokkan dalam dua jenis yaitu data primer dan data sekunder. Data primer yang digunakan dalam penelitian ini adalah persepsi konsumen mengenai objek penelitian sesuai dengan indikator yang digunakan dalam penelitian ini. Data sekunder dalam penelitian ini diperoleh dari berbagai sumber seperti website Zalora serta jurnal-jurnal ilmiah.

Berdasarkan sifatnya, data penelitian dapat dikelompokkan dalam dua jenis yaitu data kualitatif dan data kuantitatif. Data kualitatif dalam penelitian ini yaitu gambaran umum obyek penelitian. Penelitian ini menggunakan data kuantitatif berupa data jumlah responden menurut umur, jenis kelamin, dan pendidikan.

Populasi dalam penelitian ini merupakan wanita ataupun pria konsumen yang pernah membeli produk fashion secara online di Kota Denpasar. Teknik dalam pengambilan sampel menggunakan teknik purposive sampling. Menurut Kasiram (2008) teknik purposive sampling mementingkan ciri ataupun sifat tertentu yang dipandang memiliki keterkaitan erat dengan ciri atau sifat populasi yang telah diketahui sebelumnya. Teknik ini tidak memberikan kesempatan yang sama pada semua populasi untuk dijadikan sampel. Purposive sampling pada penelitian ini adanya kriteria sampling yang sangat wajib diperhatikan yaitu responden yang telah berumur 17 tahun keatas. Pertimbangan ini digunakan dengan alasan seseorang yang berumur 17 tahun keatas dapat lebih mengerti isi kuesioner yang akan diberikan dan mampu membuat keputusan sendiri. Metode yang digunakan untuk mengumpulkan data adalah survei serta observasi. Survei dilakukan dengan menyebar kuesioner kepada responden yang telah memenuhi kriteria. Pengujian pada instrumen yang dilakukan dalam penelitian ini merupakan uji validitas dan reliabilitas.

Teknik analisis data yang digunakan adalah analisis jalur dan uji sobel. Analisis jalur merupakan perluasan dari analisis regresi linear berganda, atau analisis jalur adalah penggunaan analisis regresi untuk menaksir hubungan kausalitas antar variabel (model causal) yang telah ditetapkan sebelumnya. Analisis model jalur (path) harus terlebih dahulu dibuat model jalur untuk menguji ada tidaknya peran mediasi. Model jalur merupakan suatu diagram yang menghubungkan antara variabel bebas, perantara dan tergantung (Sarwono, 2007). Dalam analisis jalur, pola hubungan ditunjukkan dengan menggunakan anak panah, dimana anak panah tunggal menunjukan hubungan sebab akibat antara variabel exogenous dan endogenus. Model persamaan jalur dalam penelitian ini adalah sebagai berikut:

$$
\begin{aligned}
& \mathrm{M}={ }_{\beta} \mathrm{X} 1+\mathrm{e}_{1} \text {. } \\
& \mathrm{Y}={ }_{\beta 1} \mathrm{X} 1+\beta \mathrm{M}+\mathrm{e}_{2} \\
& \text { Keterangan: } \\
& \mathrm{Y}=\text { keputusan pembelian } \\
& \mathrm{M}=\text { brand image }
\end{aligned}
$$


$\beta 1=$ koefisien regresi variabel price berpengaruh langsung terhadap variabel keputusan pembelian

$\beta 2=$ koefisien regresi variable brand image berpengaruh langsung terhadap variabel keputusan pembelian

$\beta 3=$ koefisien regresi variabel price berpengaruh langsung terhadap variabel brand image

$\mathrm{X} 1=$ price

$\mathrm{e}_{1}=$ error of term

$\mathrm{e}_{2}=$ error of term

Variabel dikatakan sebagai variabel intervening apabila mempengaruhi hubungan antara variabel independen dan dependen (Ghozali, 2011). Pengujian terhadap hipotesis mediasi digunakan Uji Sobel. Pengujian Uji Sobel dilakukan dengan menguji pengaruh tidak langsung variabel $\mathrm{X}$ (kewajaran harga) terhadap variabel Y (keputusan pembelian) melalui variabel intervening yaitu citra merek. Apabila hasil perhitungan $\mathrm{Z}$ hitung lebih besar dari 1,96 dengan tingkat kepercayaan 95 persen maka variabel mediasi secara signifikan memediasi hubungan variabel eksogen dan endogen.

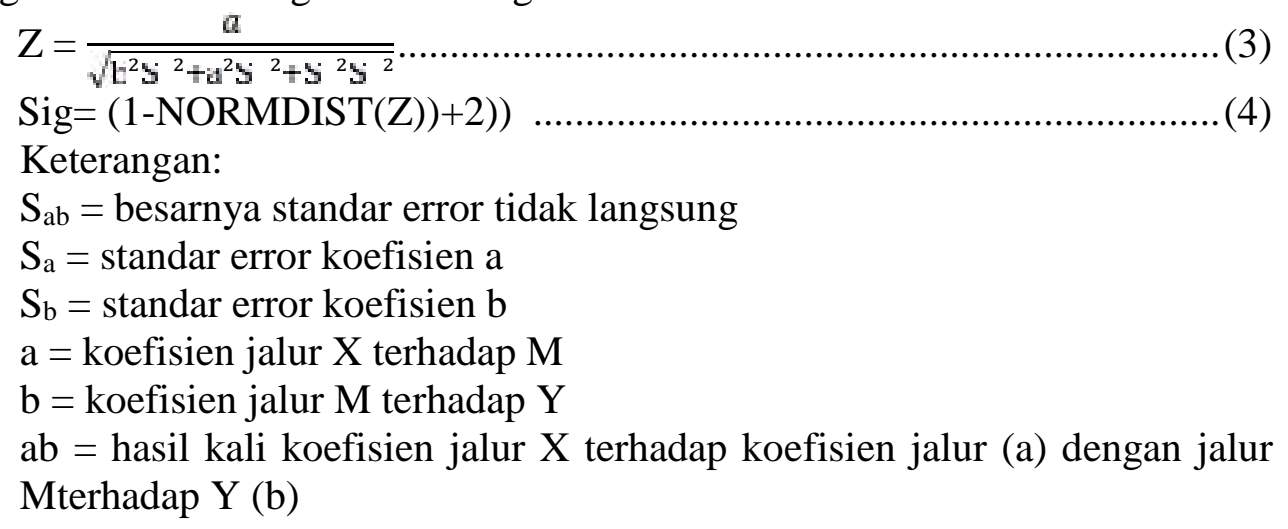

\section{HASIL DAN PEMBAHASAN}

Tabel 1.

Karakteristik Responden Berdasarkan Jenis Kelamin

\begin{tabular}{lcc}
\hline \multicolumn{1}{c}{ Klasifikasi } & Jumlah (Orang) & Presentase (\%) \\
\hline Laki-laki & 33 & 30 \\
Perempuan & 77 & 70 \\
Total & 110 & 100 \\
\hline
\end{tabular}

Sumber: Data Primer Diolah, 2017

Responden laki-laki pada penelitian ini sebesar 30\% atau sebanyak 33 orang dan responden perempuan sebesar $70 \%$ atau sebanyak 77 orang.

Pada Tabel 2. responden dengan rentang usia 21-25 tahun mendominasi sebanyak 85 orang atau sebesar $22,3 \%$.

Pada Tabel 3. responden dengan jenjang pendidikan sarjana mendominasi pada penelitian ini sebanyak 53 orang atau sebesar $48,2 \%$. 
Tabel 2.

Karakteristik Responden Berdasarkan Usia

\begin{tabular}{ccc}
\hline Usia (Tahun) & Jumlah (Orang) & Presentase (\%) \\
\hline $17-20$ & 18 & 16,4 \\
$21-25$ & 85 & 77,3 \\
$26-30$ & 5 & 4,5 \\
$31-35$ & 1 & 0,9 \\
$<35$ & 1 & 9,9 \\
Total & 110 & 100 \\
\hline
\end{tabular}

Sumber: Data Primer Diolah, 2017

Tabel 3.

Karakteristik Responden Berdasarkan Tingkat Pendidikan

\begin{tabular}{|c|c|c|}
\hline Tingkat Pendidikan & Jumlah (Orang) & Presentase $(\%)$ \\
\hline Pelajar/Mahasiswa & 49 & 44,5 \\
\hline Diploma & 6 & 5,5 \\
\hline Sarjana & 53 & 48,2 \\
\hline Lainnya & 2 & 1,8 \\
\hline Total & 110 & 100 \\
\hline
\end{tabular}

Sumber: Data Primer Diolah, 2017

Tabel 4.

Karakteristik Responden Berdasarkan Pekerjaan

\begin{tabular}{ccc}
\hline Pekerjaan & Jumlah (orang) & Presentase (\%) \\
\hline Pelajar/Mahasiswa & 60 & 54,5 \\
Wiraswasta & 7 & 6,4 \\
Pegawai Negeri Sipil (PNS) & 4 & 3,6 \\
Pegawai Swasta & 21 & 19,1 \\
Lainnya & 18 & 16,4 \\
Total & 110 & 100 \\
\hline
\end{tabular}

Sumber: Data Primer Diolah, 2017

Data responden diatas menunjukan responden pelajar/mahasiswa yang paling banyak dengan persentase sebesar $54,5 \%$ atau 60 orang.

Kewajaran harga merupakan variabel bebas dalam penelitian ini. Variabel kewajaran harga diukur dengan menggunakan 4 pernyataan yang dapat memberikan gambaran penilaian dari konsumen untuk dapat mengukur bagaimana peran kewajaran hargapada online shop Zalora. Pernyataan mengenai harga yang ditawarkan online shop Zalora dapat bersaing dengan harga pada online shop lainnya, kemudian harga yang dibayarkan konsumen dirasa puas dengan kualitas produk online shop Zalora memiliki skor rata-rata tertinggi yaitu 3,8. Pernyataan mengenai keterjangkauan harga produk fashion Zalora memiliki skor rata-rata terendah yaitu 3,6. Berdasarkan data tersebut dapat dijelaskan bahwa 4 (empat) pernyataan yang berupa indikator terkait penilaian variabel price masuk dalam kriteria tinggi. Hal ini menunjukkan bahwa responden menilai harga produk fashion yang ditawarkan online shop Zalora terjangkau.

Variabel citra merek merupakan variabel mediasi dalam penelitian ini. Citra merekdiukur dengan menggunakan 4 pernyataan melalui penilaian responden 
mengenai pernyataan yang tertuang di dalamnya. Nilai rata-rata tertinggi penilaian responden ditunjukkan pada pernyataan "Produk-produk yang ditawarkan online shop Zalora adalah produk dengan kualitas baik", dengan skor rata-rata sebesar 4,0. Hal ini menunjukkan bahwa produk-produk yang ditawarkan oleh Zalora merupakan produk dengan kualitas yang baik. Apabila dilihat secara keseluruhan, rata-rata jawaban responden masuk kedalam kategori tinggi sehingga mengartikan bahwa citra merek yang dimiliki online shop Zalora baik dimata konsumen.

Keputusan pembelian merupakan variabel terikat dalam penelitian ini. Keputusan pembelian diukur dengan menggunakan 3 pernyataan melalui penilaian responden mengenai pernyataan yang tertuang di dalamnya. Rata-rata jawaban tertinggi konsumen terdapat pada pernyataan "Saya akan membeli produk fashion di online shop Zalora kembali", dengan skor rata-rata 3,8. Pada pernyataan tersebut responden yang menjawab tidak setuju sebesar 0,9 persen, yang menjawab netral sebesar 23,5 persen, yang menjawab setuju adalah sebesar 54,2 persen, dan responden yang menjawab sangat setuju sebesar 21,4 persen. Pernyataan dengan rata-rata terendah adalah "Teman atau kerabat saya selalu merekomendasikan online shop Zalora", dengan skor rata-rata yaitu 3,4. Pada pernyataan tersebut responden yang menjawab tidak setuju sebesar 7,5 persen, responden yang menjawab netral sebesar 32,5 persen, responden yang menjawab setuju sebesar 48 persen dan responden yang menjawab sangat setuju sebesar 9,3 persen. Berdasarkan data tersebut dapat dilihat secara umum responden menilai keputusan pembelian terhadap produk fashion online shop Zalora cukup tinggi.

Tujuan penggunaan analisis faktor dalam penelitian ini adalah untuk memperoleh skor regresi faktor untuk masing-masing variabel yang digunakan dalam penelitian ini.Berikut ini disajikan hasil analisis faktor berdasarkan tahapan yang ada dalam analisis faktor.

Correlation Matrix, matriks korelasi digunakan untuk mengidentifikasikan variabel-variabel tertentu yang tidak mempunyai korelasi dengan variabel lain, sehingga dapat dikeluarkan dari analisis. Hasil penelitian menunjukkan bahwa koefisien determinasi dari masing-masing variabel sudah mendekati nilai 0 , sehingga dapat dinyatakan bahwa item instrumen dari masing-masing variabel memiliki korelasi yang kuat.

Kaiser Meyer Olkin (KMO), Uji Kaiser Meyer Olkin (KMO) dilakukan untuk mengetahui kecukupan sampelnya. Analisis faktor dianggap layak jika besaran KMO nilainya minimal 0,5. Hasil uji Kaiser Meyer Olkin (KMO) pada penelitian ini menunjukkan bahwa nilai Kaiser Meyer Olkin (KMO) untuk masing-masing variabel lebih besar dari 0,5 sehingga dapat dinyatakan bahwa masing-masing variabel mempunyai kecukupan sampel untuk melakukan analisis faktor.

Measures of Sampling Adequancy (MSA), Kelayakan model uji faktor untuk masing-masing variabel dapat dilihat dari nilai Measures of Sampling Adequancy (MSA). Nilai MSA instrumen dari masing-masing variabel pada penelitian ini menunjukkan bahwa nilai MSA instrumen dari masing-masing variabel lebih besar dari 0,5. Dapat dinyatakan bahwa masing-masing model layak digunakan dalam model uji faktor. 
Percentage of Variance, menjelaskan kemampuan dari masing-masing faktor untuk menjelaskan variasinya. Nilai Percentage of Variance untuk masingmasing variabel pada penelitian ini menunjukkan bahwa Percentage of Variance untuk masing-masing tabel lebih besar dari 60 persen. Jadi dapat dinyatakan bahwa faktor dari masing-masing variabel memiliki kelayakan kemampuan untuk menjelaskan variasi faktornya.

Uji validitas instrumen pada penelitian ini bertujuan untuk dapat menguji apakah butir-butir pernyataan yang ada di dalam kuisioner sudah valid. Suatu instrumen dapat dikatakan sudah valid apabila terdapat korelasi antar skor faktor dengan skor total yang bernilai positif dan memiliki nilai yang lebih besar dari $0,30(\mathrm{r}>0,3)$. Tabel 5. merupakan hasil uji validitas instrumen pada penelitian ini.

Tabel 5.

Hasil Uji Validitas Instrumen

\begin{tabular}{ccccc}
\hline No & Variabel & Item Pernyataan & Person Correlation & Keterangan \\
\hline 1 & Kewajaran harga & $\mathrm{X}_{1.1}$ & 0,798 & Valid \\
& $(\mathrm{X} 1)$ & $\mathrm{X}_{1.2}$ & 0,632 & Valid \\
& & $\mathrm{X}_{1.3}$ & 0,798 & Valid \\
& & $\mathrm{X}_{1.4}$ & 0.905 & Valid \\
& Citra Merek(M) & $\mathrm{M}_{1.1}$ & 0,894 & Valid \\
& & $\mathrm{M}_{1.2}$ & 0,846 & Valid \\
& $\mathrm{M}_{1.3}$ & 0,853 & Valid \\
& $\mathrm{M}_{1.4}$ & 0,817 & Valid \\
& & & \\
& & & 0,867 & Valid \\
& & $\mathrm{Y}_{1}$ & 0,850 & Valid \\
& Keputusan & $\mathrm{Y}_{2}$ & 0,880 & Valid \\
& Pembelian (Y) & $\mathrm{Y}_{3}$ & & \\
& & & &
\end{tabular}

Sumber : Data diolah, 2017

Hasil dari uji validitas menyatakan bahwa variabel-variabel tersebut memiliki nilai koefisien korelasinya dengan skor total pada seluruh item pernyataan tersebut lebih besar dari 0,30 , maka setiap butir pernyataan telah dinyatakan valid.

Uji Reliabilitas instrument pada penelitian ini digunakan untuk dapat mengetahui adanya konsistensi setiap alat ukur dalam penggunaannya. Suatu instrumen dapat dikatakan reliabel, jika instrumen tersebut telah memiliki nilai Alpha Cronbach lebih besar dari 0,6. Nilai Cronbach's Alpha antara 0,80 - 1,0 dikategorikan reliabilitas baik, nilai 0,60-0,79 dikategorikan reliabilitasnya dapat diterima, nilai $\leq 0,60$ dikategorikan reliabilitasnya buruk (Sekaran, 2006).

Tabel 6.

Hasil Uji Reliabilitas Instrumen Penelitian

\begin{tabular}{llll}
\hline No & \multicolumn{1}{c}{ Variabel } & Cronbach'sAlpha & Keterangan \\
& & & \\
\hline 1 & Kewajaran Harga (X1) & 0,784 & Reliabel \\
2 & Citra Merek (M) & 0,868 & Reliabel \\
3 & Keputusan Pembelian (Y) & 0,832 & Reliabel \\
\hline \multicolumn{2}{l}{ Sumber $:$ Data diolah, 2017}
\end{tabular}


Hasil uji reliabilitas menunjukan bahwa seluruh instrumen dalam penelitian memiliki koefisien Cronbach's Alpha lebih besar dari 0,60. Hal ini dapat dikatakan bahwa semua instrumen dinyatakan reliabel sehingga dapat digunakan untuk melakukan penelitian.

Tabel 7.

Path Coefficients

\begin{tabular}{cccc}
\hline $\begin{array}{c}\text { Pengaruh } \\
\text { Variabel }\end{array}$ & $\begin{array}{c}\text { Pengaruh } \\
\text { Langsung }\end{array}$ & $\begin{array}{c}\text { Pengaruh Tidak Langsung Melalui } \\
\text { Citra merek }\end{array}$ & Pengaruh Total \\
\hline $\mathrm{X}_{1} \rightarrow \mathrm{Y}$ & 0,368 & - & 0,368 \\
$\mathrm{X}_{1} \rightarrow \mathrm{Y}$ & 0,368 & $0,732 \times 0,491=0,360$ & 0,728 \\
$\mathrm{M} \rightarrow \mathrm{Y}$ & 0,491 & - & 0,491 \\
\hline
\end{tabular}

Sumber : Data diolah, 2017

Berdasarkan hasil Tabel 7. dapat dijelaskan bahwa pengaruh keterjangkauan harga berpengaruh positif signifikan terhadap keputusan pembelian dengan koefisien positif yaitu 0,368. Apabila keterjangkauan harga yang dirasakan oleh konsumen meningkat maka akan meningkatkan keputusan pembelian. Citra merek secara positif dan signifikan mempengaruhi keputusan pempebial dengan koefisien positif yaitu 0,491, apabila citra merek menngkat maka akan mempengaruhi atau meningkatkan keputusuan pembelian konsumen.

Tabel 8.

Uji Sobel

\begin{tabular}{rc}
\hline Nilai Z & Sig \\
\hline 5,5113 & 0,000 \\
\hline Sumber $:$ Data diolah (2017) &
\end{tabular}

Nilai $Z_{\text {hitung }}$ yang diperoleh dari hasil perhitungan Uji Sobel adalah sebesar 5,5113, dari hasil ini menunjukan bahwa citra merek secara signifikan memediasi kewajaran harga terhadap keputusan pembelianproduk fashion online shop ZALORA.

\section{SIMPULAN}

Hasil penelitian ini adalah : (1) Kewajaran hargamemiliki pengaruh yang positif dan signifikan terhadap keputusan pembelian produk fashion online shop ZALORA di Kota Denpasar. Hal ini menunjukan konsumen berpersepsi bahwa harga yang ditawarkan telah sesuai dengan manfaat yang dapat diterima, dan berdampak positif bagi keputusan pembelian konsumen. (2) Citra merek memiliki pengaruh yang positif dan signifikan terhadap keputusan pembelian. Artinya bahwa semakin baik citra merek ZALORA maka akan berpengaruh positif pula terhadap keputusan pembelian konsumen. (3) Citra merek secara signifikan memediasi pengaruh keterjangkauan harga terhadap keputusan pembelian produk 
fashion online shop ZALORA di Kota Denpasar. Hal ini berarti bahwa keterjangkauan harga berpengaruh pada keputusan untuk membeli produk fashion online shop ZALORA melalui citra merek. Harga produk yang ditetapkan ZALORA berpengaruh terhadap citra merekyang tercipta di mata konsumen. Citra merek yang baik akan meningkatkan keputusan pembelian konsumen terhadap produk fashion online shop ZALORA.

Bagi perusahaan, persaingan antar online shop saat ini sangat ketat, kedepannya diharapkan ZALORA mampu mampu menetapkan harga yang tepat dan meningkatkan brand image dimata konsumen, brand image yang positif akan menjadi daya Tarik tersendiri bagi online shop ZALORA. Komponen yang perlu ditingkatkan bukan hanya kewajaran harga dan brand image saja namun dapat mempertimbangkan komponen lainnya untuk menunjang keputusan pembelian terhadap produk fashion online shop ZALORA. Memberikan potongan harga khusus, dan memberikan penawaran khusus seperti memposting pada social media membatu Zalora dalam meningkatkan promosi dan menarik minat konsumen untuk membeli ataupun konsumen yang suah pernah membeli untuk melakukan pembelian ulang.

Bagi peneliti selanjutnya diharapkan nantinya dapat memperluas cakupan penelitiannya, tidak hanya pada keputusan pembelian saja, namun dapat mengembangkan pada niat beli ataupun loyalitas konsumen, bagaimana konsumen dapat loyal terhadp suatu produk barang ataupun jasa faktor apa yang mampu mempengaruhi sikap dan perilaku konsumen dalam melakukan keputusan.

\section{REFERENSI}

Abdul Samad, \& Imam Wibowo. (2016). Pengaruh Produk dan Citra Merek Terhadap Keputusan Pembelian Sepatu Olahraga Merek Specs Di Kota Bekasi. Jurnal Manajemen Bisnis Krisnadwipayana, 4(3), 1-9.

Achidah, N., Hasiolan, L. B., \& Warso, M. M. (2016). Pengaruh Promosi, Harga, Dan Desain Terhadap Keputusan Pembelian Sepeda Motor Mio GT (Study Empiris Pada Produk Yamaha Mio GT Di Weleri-Kendal) Nur. Journal of Management, 2(2).

Akbar, S., \& James, P. T. (2012). Consumers ' Attitude Towards Online Shopping: Factors Influencing Employees of Crazy Domains to Shop Online. Journal of Management and Marketing Research, 1-11.

Alif Fianto, A. Y., Hadiwidjojo, D., Aisjah, S., \& Solimun, S. (2014). The Influence of Brand Image on Purchase Behaviour Through Brand Trust. Business Management and Strategy, 5(2), 58. https://doi.org/10.5296/bms.v5i2.6003

Ambarwati, D. A. S. (2015). Analisis Green Marketing pada Perilaku dan Sikap Konsumen. Jurnal Bisnis Dan Manajemen, 11(1), 47-66.

Baubonien , Ž., \& Gulevičiūt , G. (2015). E-Commerce Factors Influencing 
Consumers' Online Shopping Decision. Socialnès Technologijos, 5(01), 7481. https://doi.org/10.13165/ST-15-5-1-06

Chen, L. D., Liang, H. G., Lai, X., Wang, N. M., \& Huang, W. (2016). Research in progress: The snob and bandwagon effects on consumers' purchase intention under different promotion strategies. Pacific Asia Conference on Information Systems, PACIS 2016 - Proceedings.

Díaz-Bonilla, E. (2016). Volatile volatility: Conceptual and measurement issues related to price trends and volatility. Food Price Volatility and Its Implications for Food Security and Policy, 35-57. https://doi.org/10.1007/978-3-319-28201-5_2

Dodds, W., \& Monroe, K. (1985). The Effect of Brand and Price Information on Subjective Product Evaluations. ACR North American Advances, NA12(1977), 1-5.

Durrani, B. A., \& Lecturer, S. (2015). Impact of Brand Image on Buying Behaviour Among Teenagers. European Scientific Journal, 11(5), 155-168. https://doi.org/10.19044/esj.2015.v11n5p\%p

Faith, D. O., \& Edwin, A. M. (2014). A Review of The Effect of Pricing Strategies on The Purchase of Consumer Goods. International Journal of Research in Management, Science \& Technology, 2(2), 2321-3264.

Fristiana, D. A. (2012). Pengaruh Citra Merek dan Harga Terhadap Keputusan Pembelian Pada Ramai Swalayan Peterongan Semarang. Jurnal Ilmu Administrasi Bisnis, 1(1), 1-9.

Gázquez-Abad, J. C., \& Martínez-López, F. J. (2014). How Assortment Composition Affects Consumers' Intentions to Buy PL. National Brands and Private Labels in Retailing. Springer Proceedings in Business and Economics, 27-37. https://doi.org/10.1007/978-3-319-07194-7_3

Geçti, F. (2014). Examining Price Perception and The Relationship Among Its Dimentions Via Structural Equation Modeling: A Research on Turkish Consumers. British Journal of Marketing Studies, 2(1), 1-11.

Ghozali, I. (2011). Aplikasi Analisis Multivariate dengan Program SPSS. Semarang: Badan Penerbit Universitas Diponegoro.

Habibah, U., \& Sumiati. (2016). Pengaruh Kualitas Produk Dan Harga Terhadap Keputusan Pembelian Produk Kosmetik Wardah Di Kota Bangkalan Madura. Jurnal Ekonomi Dan Bisnis, 1(1), 660-667.

Irmawati, D. (2011). Pemanfaatan E-Commerce Dalam Dunia Bisnis. Jurnal Ilmiah Orasi Bisnis, VI(11), 95-112. 
Kasiram, M. (2008). Metodologi Penelitian. Malang: UIN-Malang Pers.

Kenesei, Z., \& Todd, S. (2003). The use of price in the purchase decision. Journal of Empirical Generalisations in Marketing Science, 8, 1-22.

Kotler, P., \& Keller, R. T. (2009). Manajemen Pemasaran (13th ed.). Jakarta: Erlangga.

Lim Lay-Yee, K., Kok-Siew, H., \& Chan Yin-Fah, B. (2013). Factors Affecting Smartphone Purchase Decision Among Malaysian Generation Y. International Journal of Asian Social Science, 3(312), 2426-2440. Retrieved from http://www.aessweb.com/journal-detail.php?id=5007

Lingga, R. U. (2016). Pengaruh Brand ImageTerhadap Keputusan Konsumen. EJurnal Ilmu Administrasi Bisnis, 4(2), 400-414.

Mangkunegara, A. P. (2015). Manajemen Sumber Daya Manusia Perusahaan. Bandung: Remaja Rosdakarya.

Mobarakabadi, H., Karami, M., Far, S. M., \& Yarkarami, K. (2013). Influence of online shopping behavior factors on E-satisfaction of customer. Jurnal Teknologi (Sciences and Engineering), 64(3), 1-7. https://doi.org/10.11113/jt.v64.2257

Müller, B., \& Chandon, J.-L. (2003). The Impact of Visiting a Brand Website on Brand Personality. Electronic Markets, 13(3), 210-221. https://doi.org/10.1080/1019678032000108301

Nugroho, J. P. (2014). Analisis Pengaruh Kualitas Produk dan Citra Merek Terhadap Kepuasan Konsumen Dalam Meningkatkan Word of Mouth Pada Produk Autan. Skripsi. Fakultas Ekonomika dan Bisnis Universitas Diponegoro Semarang.

Nurul, E. (2017). Pengaruh Citra Merek Terhadap Keputusan Pembelian (Studi Kasus Pada Bakso Boedjangan Cabang Burangrang Bandung Tahun 2017). E-Proceeding of Applied Science, Vol.3(2), 438. Retrieved from https://openlibrary.telkomuniversity.ac.id/pustaka/135770/pengaruh-citramerek-terhadap-keputusan-pembelian-studi-kasus-pada-bakso-boedjangancabang-burangrang-bandung-tahun-2017-.html

Owusu, A. (2013). Influences of Price And Quality On Consumer Purchase Of Mobile Phone In The Kumasi Metropolis In Ghana A Comparative Study. European Journal of Business and Management, 5(1), 2222-2839. Retrieved from http://citeseerx.ist.psu.edu/viewdoc/download?doi=10.1.1.919.9957\&rep=rep $1 \&$ type $=$ pdf

Pahwa, B., Taruna, S., \& Kasliwal, N. (2017). Role of Data mining in analyzing 
consumer's online buying behavior. International Journal of Business and Management Invention ISSN (Online, 6(11), 2319-8028. Retrieved from www.ijbmi.org

Purnamasari, S. (2015). Brand Image sebagai Mediasi Pengaruh Promosi, Harga, dan Sikap Konsumen terhadap Keputusan Pembelian Jamu Nyonya Meneer di Semarang Timur. Skripsi. Sarjana Jurusan Manajemen Fakultas Ekonomi Universitas Negeri Semarang.

Rohmah, S. (2015). Pengaruh Citra Merek, Kualitas Produk, dan Layanan Terhadap Keputusan Pembelian Produk Perhiasan. Jurnal Ilmu Dan Riset Manajemen, 4(5), 1-15.

Sallam, M. A. (2014). The Effects of Brand Image and Brand Identification on Brand Love and Purchase Decision Making: The Role of WOM. International Business Research, 7(10), 187-193. https://doi.org/10.5539/ibr.v7n10p187

Sarwono, J. (2007). Analisis Jalur untuk Riset Bisnis dengan SPSS. Yogyakarta: Andi Offset.

Schiffman, L. G., \& Kanuk, L. L. (2010). Consumer Behavior (10th ed.). Pearson Education.

Sekaran, U. (2006). Metode Penelitian Bisnis. Jakarta: Salemba Empat.

Sidharta, I., \& Boy Suzanto. (2015). Pengaruh Kepuasan Transaksi Online Shopping Dan Kepercayaan Konsumen Terhadap Sikap Serta Perilaku Konsumen Pada E-Commerce. Jurnal Computech \& Bisnis, 9(1), 23-36. Retrieved from http://jurnal.stmikmi.ac.id/index.php/jcb/article/download/124/148

Sugiyono. (2014). Metode Penelitian Bisnis. Bandung: Alfabeta.

Tjahjono, A., Semuel, P. H., Karina, R., Pemasaran, J. M., Petra, U. K., \& Siwalankerto, J. (2013). Analisa Marketing Mix , Lingkungan Sosial , Psikologi Online Pakaian Wanita. Jurnal Manajemen Pemasaran Petra, 1(2), 1-9.

Wahyuni, N., \& Suparna, G. (2014). Pengaruh Brand Image dan Product Knowledge Terhadap Purchase intention Produk Tas Tiruan Di Kota Denpasar. E-Jurnal Manajemen Universitas Udayana, 3(4), 1022-1034.

Wanda. (2015). Keputusan Pembelian Di Mini Market Lulu Mart Samarinda. EJournal Ilmu Administrasi Bisnis, 3(4), 757-768.

Wang, Y.-H., \& Tsai, C.-F. (2014). The Relationship between Brand Image and Purchase Intention: Evidence from Award Winning Mutual Funds. The 
Ni Putu Lely Wahyuni, Peran Citra Merek...

International Journal of Business and Finance Research, 8(2), 27.

Widiyanto, I., \& Prasilowati, S. L. (2015). Perilaku Pembelian Melalui Internet. Jurnal Manajemen Dan Kewirausahaan (Journal of Management and Entrepreneurship), 17(2), 109-112. https://doi.org/10.9744/jmk.17.2.109122

Zhang, Y. (2015). The impact of brand image on consumer behavior. Open Journal of Business and Management, 3(1), 58-62. 